\title{
Plant Establishment in Masticated Utah Juniper Woodlands
}

\author{
Kert R. Young, ${ }^{1}$ Bruce A. Roundy, ${ }^{2}$ and Dennis L. Eggett ${ }^{3}$ \\ Authors are ${ }^{1}$ Research Associate and ${ }^{2}$ Professor, Department of Plant and Wildlife Sciences, Brigham Young University, Provo, UT 84602, USA; and \\ ${ }^{3}$ Associate Professor, Department of Statistics, Brigham Young University, Provo, UT 84602, USA.
}

\begin{abstract}
Juniper (Juniperus spp.) encroachment into sagebrush (Artemisia spp.)-bunchgrass communities has reduced understory cover on millions of hectares of semiarid rangelands. Mechanical masticators shred trees to restore desirable vegetation and reduce the potential for catastrophic wildfire. Mechanical mastication where juniper density is high and perennial grass cover is low brings a risk of invasive weed dominance unless perennial species are established. To determine whether juniper mastication favors annual- or perennial-grass establishment, we compared seedling emergence, tillers, and aboveground biomass of cheatgrass (Bromus tectorum L.) and Anatone bluebunch wheatgrass (Pseudoroegneria spicata [Pursh] A. Löve). Comparisons were made among hand-planted rows between and under juniper canopies of masticated and adjacent untreated control areas at three locations in Utah. Bluebunch wheatgrass had 16\% (95\% CI: 11-21) and cheatgrass had 10\% (95\% CI: 5-15) fewer seedlings emerge per row in masticated than untreated areas $(P<0.001)$. However, bluebunch wheatgrass had 3.2 (95\% CI: 2.0-5.2) times more tillers and 1.9 (95\% CI: 1.6-2.2) times more aboveground biomass per row in masticated than untreated areas $(P<0.001)$. Similarly, cheatgrass had 2.3 (95\% CI: 1.5-3.8) times more tillers, 2.0 (95\% CI: 1.7-2.4) times more aboveground biomass, and 11.4 (95\% CI: 6.3-20.7) times more spikelets per row in masticated than untreated areas $(P<0.001)$. This increased seedling growth in masticated areas was associated with increased inorganic nitrogen and soil water compared to untreated areas. Because mastication improves the growth of both cheatgrass and bluebunch wheatgrass seedlings, it could support dominance by either annual- or perennial-life forms. To avoid cheatgrass dominance where perennial understory cover is limited and cheatgrass propagule pressure is high, mastication should be accompanied by seeding desirable perennial species such as Anatone bluebunch wheatgrass.
\end{abstract}

Key Words: grass emergence, invasive weeds, mulch, resilience, resistance, resource availability

\section{INTRODUCTION}

Juniper (Juniperus spp.) encroachment into sagebrush (Artemisia spp.) and bunchgrass communities has reduced understory plant cover and resulted in juniper domination on millions of hectares of semiarid rangelands (Miller et al. 2005). Juniper encroachment is mainly attributed to reduced fire frequency and a mild wet climate in the late 1800s and early 1900s (Miller and Rose 1999). Reduced fire resulted from heavy livestock grazing during the late 1800s and early 1900s that reduced fine fuels needed to carry fire (Burkhardt and Tisdale 1976). The reduction of herbaceous vegetation also reduced resource competition and allowed shrubs to increase in size and provide safe sites for juniper establishment (Miller and Rose 1999). Juniper encroachment into and domination of these communities is associated with formation of resources islands as trees transfer soil nutrients and water away from plants in interspaces to subcanopy litter mounds through roots and canopy dropped leaf scales, fruits, and twigs (Schlesinger and Pilmanis 1998; Newman et al. 2010).

\footnotetext{
This is contribution number 95 of the Sagebrush Steppe Treatment Evaluation Project (SageSTEP) funded by the US Joint Fire Science Program, the Bureau of Land Management, the National Interagency Fire Center, and Brigham Young University. Correspondence: Kert R. Young, Dept of Plant and Wildlife Sciences, 275 WIDB, Brigham Young University, Provo, UT 84602, USA. Email: youngke1@msn.com
}

Manuscript received 26 July 2012; manuscript accepted 13 May 2013.

(c) 2013 The Society for Range Management
Juniper-encroached lands are treated to return the plant community back to sagebrush-bunchgrass dominated systems and to reduce the potential for crown fire by reducing canopy fuel loads (Miller and Tausch 2001). A recent method of tree control is mechanical mastication that shreds canopies, branches, and trunks into surface debris. Little is known about the influence of juniper mastication on resource availability and plant community dynamics. In general, juniper control reduces competition for soil water and nutrients and thereby increases understory plant productivity (Bates et al. 2000).

Plant community response to tree reduction can vary among locations. For example, juniper control treatments have resulted in increased annual-plant cover at some locations but not at others (Barney and Frischknecht 1974; Koniak 1985; Tausch and Tueller 1997). It is not always clear why invasive annuals sometimes dominate after woody species control, but increased resource availability is thought to increase the invasibility of plant communities and reduce community resistance to invasion (Vasquez et al. 2008a). For example, increased soil inorganic nitrogen $(\mathrm{N})$ has enabled greater competitiveness and growth of invasive annual grasses over perennial grasses (Vasquez et al. 2008b). In turn, rapid annual grass growth reduces resources available to slower growing perennial grasses and reduces perennial grass vigor (Melgoza et al. 1990; Monaco et al. 2003). However, traits that endow plants with the ability to grow rapidly under high resources may reduce their ability to thrive under low resources (Grime and Hunt 1975). 
As soil inorganic $\mathrm{N}$ is usually the most limiting mineral resource to plant growth (Sylvia et al. 2005), reducing soil inorganic $\mathrm{N}$ with carbon $(\mathrm{C})$ additions in the form of sucrose has reduced the biomass and density of invasive annual grasses like cheatgrass (Bromus tectorum L.; Paschke et al. 2000; Beckstead and Augspurger 2004). Additions of C to the soil in the form of masticated trees have also reduced soil inorganic $\mathrm{N}$ in subalpine and montane forests (Rhoades et al. 2012) but have increased both native and nonnative plant cover and density (Kane et al. 2010). Organic C additions reduce soil inorganic $\mathrm{N}$ through soil microorganism use when their organic $\mathrm{C}$ energy sources do not contain sufficient $\mathrm{N}$ for metabolism and growth (Brady and Weil 1999). It is uncertain how long masticated trees might reduce soil inorganic $\mathrm{N}$ or influence plant community dynamics, but if tree mastication maintains low soil inorganic $\mathrm{N}$ levels long-term, perennial grass dominance may be favored over invasive annual grasses (Monaco et al. 2003).

The control of juniper trees not only influences inorganic $\mathrm{N}$ levels but also increases soil water availability during spring (Bates et al. 2000), a critical time for seedling establishment (Hardegree et al. 2003; Roundy et al. 2007). The availability of soil water in spring may benefit perennials more than invasive annuals because perennial grass roots like those of bluebunch wheatgrass (Pseudoroegneria spicata [Pursh] A. Löve) grow slower than invasive annuals like cheatgrass, especially during cool seasons (Harris 1967). The increased soil water availability and presumed lower inorganic $\mathrm{N}$ following tree chipping in Nevada increased perennial and decreased annual grass density and cover under woody debris (Benson 2006). However, such outcomes are dependent on pretreatment plant community composition, which may be limited where trees have dominated for several years on shallow soils (Koniak 1985; Miller et al. 2005).

Land managers need to know if mastication will favor desirable plant recovery and if they need to plant perennial grasses in combination with juniper mastication where increased tree density has reduced desirable grasses. To address these questions, our main objective was to determine if juniper mastication favors cheatgrass or bluebunch wheatgrass seedling establishment and growth. Our second objective was to isolate the effects of soil inorganic $\mathrm{N}$ on seedling establishment and growth from other mastication-altered environmental conditions using ammonium sulfate (N-S) and sucrose (C) amendments. We hypothesized that: 1) juniper tree mastication will increase bluebunch wheatgrass and cheatgrass establishment and growth by increasing resource availability; 2) litter mounds in masticated areas as resource islands and $\mathrm{N}$ fertilization will favor cheatgrass over bluebunch wheatgrass because of greater cheatgrass response to increased soil inorganic N; 3) high C:N ratio woody debris and $\mathrm{C}$ amendments will favor bluebunch wheatgrass over cheatgrass by reducing inorganic $\mathrm{N}$; and 4) interspaces between litter mounds will not favor cheatgrass or bluebunch wheatgrass establishment.

\section{MATERIALS AND METHODS}

\section{Study Locations}

Our study locations included Greenville (lat $38^{\circ} 12^{\prime} \mathrm{N}$, long $112^{\circ} 48^{\prime} \mathrm{W}$ ), Onaqui (lat $40^{\circ} 13^{\prime} \mathrm{N}$, long $112^{\circ} 28^{\prime} \mathrm{W}$ ), and Stans- bury (lat $40^{\circ} 35^{\prime} \mathrm{N}$, long $112^{\circ} 39^{\prime} \mathrm{W}$ ) in western Utah. These locations were part of the Sagebrush Steppe Treatment Evaluation Project (SageSTEP) evaluating sagebrush steppe restoration methods in the Great Basin region (www.sagestep. org). Study locations contained a range of Utah juniper (Juniperus osteosperma [Torr.] Little) encroachment typical of the Great Basin in Utah. This encroachment varied from a few trees scattered among sagebrush and bunchgrass in Phase I to abundant trees with little remaining understory cover in Phase III (sensu Miller et al. 2005). The maximum tree density ( $>0.5$ $\mathrm{m}$ tall) prior to mastication was 586 trees $\cdot \mathrm{ha}^{-1}$ at Greenville, 444 trees $\cdot \mathrm{ha}^{-1}$ at Onaqui, and 1030 trees $\cdot \mathrm{ha}^{-1}$ at Stansbury. We measured response variables in Phase III areas where pretreatment shrub cover was $<5 \%$ and perennial grass cover was $<10 \%$ at Greenville and Onaqui and $<20 \%$ at Stansbury as determined from SageSTEP measurements collected within $100 \mathrm{~m}$ of our study.

Greenville vegetation included Utah juniper (Juniperus osteosperma [Torr.] Little), two-needle piñon (Pinus edulis Engelm.), Wyoming big sagebrush (Artemisia tridentata Nutt. ssp. wyomingensis Beetle \& Young), rabbitbrush (Chrysothamnus viscidiflorus [Hook.] Nutt.), bluebunch wheatgrass (Pseudoroegneria spicata [Pursh] A. Löve), needle-and-thread (Hesperostipa comata [Trin. \& Rupr.] Barkworth), and Indian ricegrass (Achnatherum hymenoides [Roem. \& Schult.] Barkworth). Onaqui vegetation included Utah juniper, Wyoming big sagebrush, bluebunch wheatgrass, Sandberg bluegrass (Poa secunda J. Presl), and Indian ricegrass. Stansbury vegetation included Utah juniper, Wyoming big sagebrush, antelope bitterbrush (Purshia tridentata [Pursh] DC.), bluebunch wheatgrass, Sandberg bluegrass, and cheatgrass.

Soils at the three locations are loamy skeletal. Greenville soils are carbonatic, mesic Typic Calcixerepts (Rau et al. 2011). Onaqui soils are carbonatic, mesic, shallow Petrocalcic Palexerolls (Rau et al. 2011). Stansbury soils are mixed, active, frigid Pachic Haploxerolls (Rau et al. 2011). We conducted our research at $1700-1900 \mathrm{~m}$ in elevation across all three locations. Annual precipitation totals during 1970-2007 averaged $334 \mathrm{~mm}$ at Greenville, $311 \mathrm{~mm}$ at Onaqui, and 389 $\mathrm{mm}$ at Stansbury (PRISM 2008). A more complete description of the SageSTEP locations can be found in McIver et al. (2010).

\section{Treatment Implementation and Study Design}

A Tigercat M726E Mulcher (Tigercat Industries, Inc, Brantford, Ontario) with Fecon Bull Hog (Fecon, Inc, Lebanon, OH) masticated trees in fall 2006 at Onaqui and in fall 2007 at Stansbury. A skid steer loader with Fecon Bull Hog masticated trees in fall 2007 at Greenville.

We implemented a randomized complete block design using paired masticated and untreated control plots with similar soil and vegetation at each of the three locations. A masticated plot was $6-50$ ha depending on space available for research where juniper trees taller than $0.5 \mathrm{~m}$ were masticated. The differences in plot size would not be expected to alter response variables, which were measured at the microsite scale. Each plot contained four replicate blocks with two trees in untreated blocks and four trees in masticated blocks (Fig. 1). We used juniper trees with litter mounds at least $2 \mathrm{~m}$ in diameter to allow room for seeding. We divided the area around trees into 


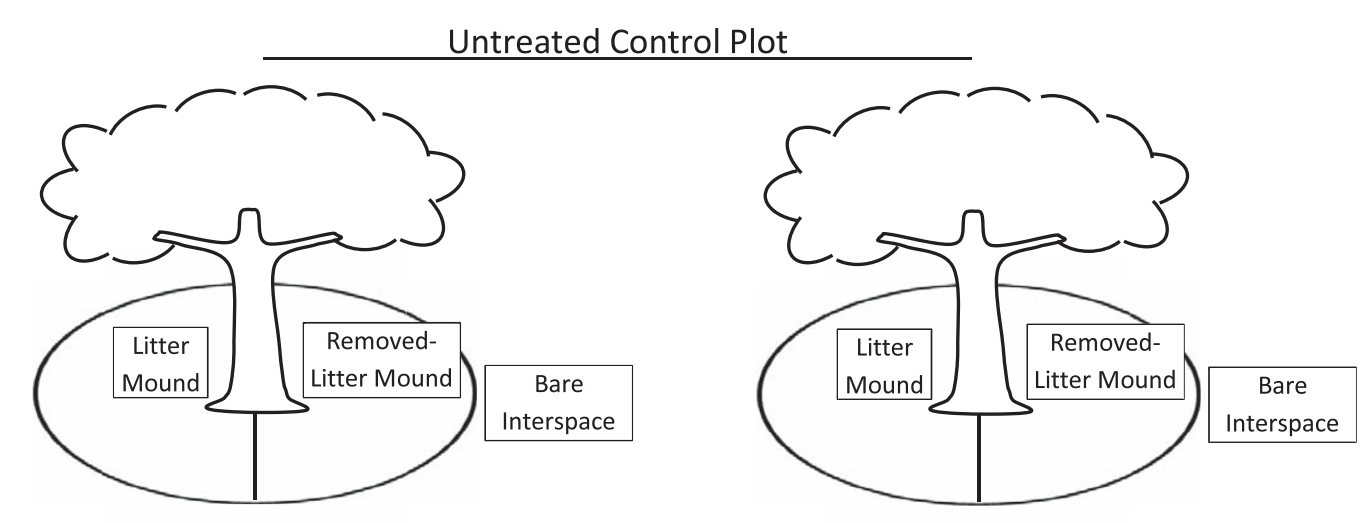

Masticated Plot
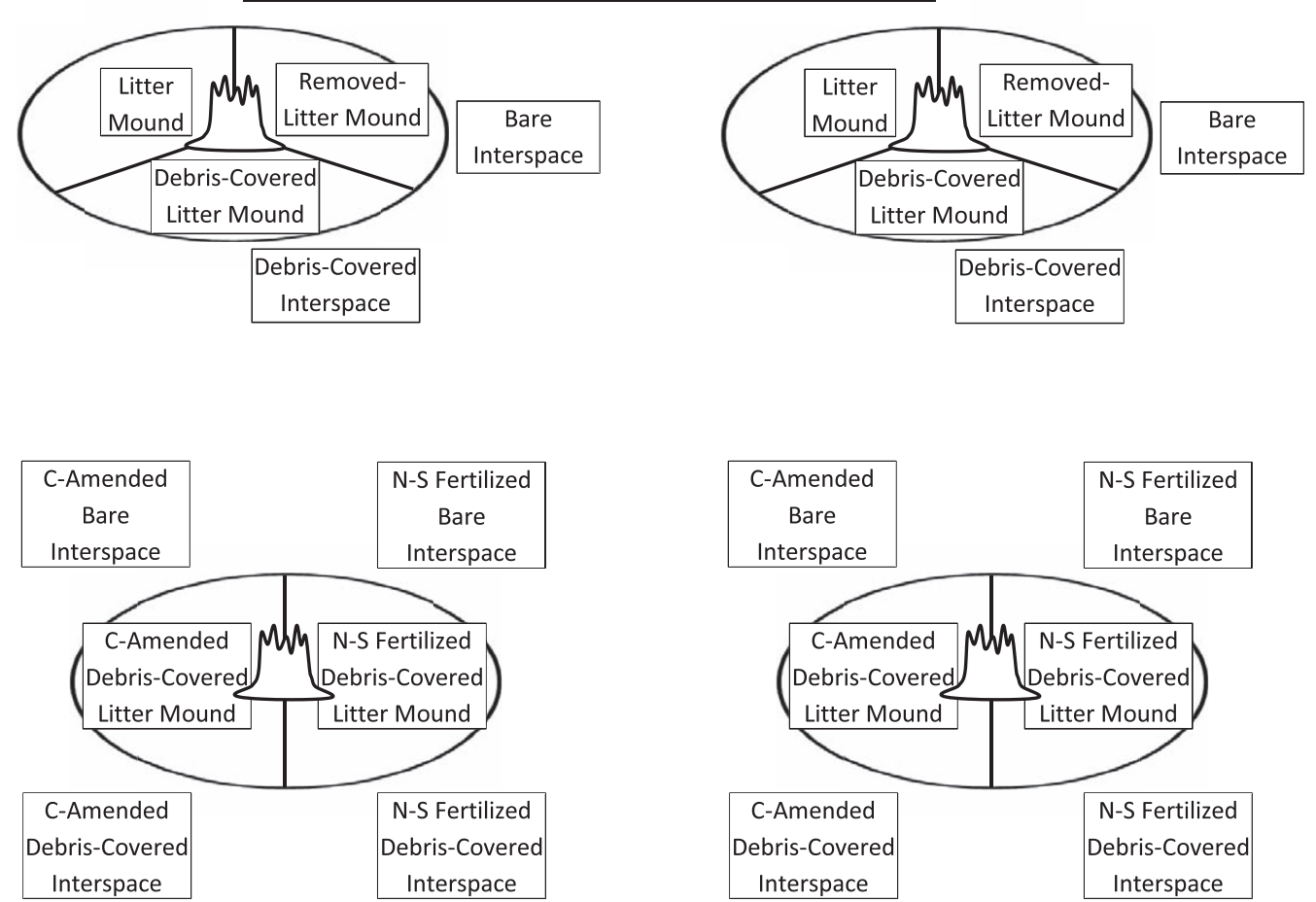

Figure 1. Treatment diagram of microsite experimental units for one of four blocks of an untreated and masticated plot at one of three study locations. Treatment design was similar for the other three blocks in each treatment plot at each location.

microsites like slices of a pie. This allowed us to make microsite comparisons that isolated the effects of debris, litter mounds, and inorganic $\mathrm{N}$ on seedling establishment and growth.

The number of microsite experimental units for seedling establishment was 112 at each of the three locations. In untreated plots, the two trees per block had three microsite types that included: 1) juniper litter mounds consisting of dead juniper scales, fruits, and twigs (litter mounds), 2) exposed soil after hand removal of litter mounds to isolate the effects of litter on seedling establishment (removed-litter mounds), and 3) interspaces between trees where little vegetation was growing (bare interspaces). In masticated plots, two of the four trees per block each had five microsite types that included: 1) litter mounds, 2) removed-litter mounds, 3) bare interspaces, 4) former bare interspaces covered with juniper debris following mastication (debris-covered interspaces), and 5) juniper litter mounds covered with juniper debris following mastication (debris-covered litter mounds).

The other two trees per block in masticated plots had two sets of microsites with each set having a bare interspace, debriscovered interspace, and debris-covered litter mound per tree (Fig. 1). One set of these three microsite types per tree received $1100 \mathrm{~kg} \cdot \mathrm{ha}^{-1}$ of $\mathrm{C}$ applied in the form of sucrose $\left(\mathrm{C}_{12} \mathrm{H}_{22} \mathrm{O}_{11}\right)$. The other set received $224 \mathrm{~kg} \cdot \mathrm{ha}^{-1}$ of $\mathrm{N}$ applied in the form of ammonium sulfate $\left(\left[\mathrm{NH}_{4}\right]_{2} \mathrm{SO}_{4}\right)$ that we refer to as N-S fertilizer. We amended the soil to determine the effects of an extreme range of soil $\mathrm{N}$ availability on seedling establishment isolated from other potential mastication-induced chang- 
es in environmental conditions. Amendments of N-S and C were applied once each fall at Greenville in October 2008 and November 2009, Onaqui in October 2007 and October 2008, and Stansbury in October 2008.

In every microsite, 40 seeds of Anatone bluebunch wheatgrass and cheatgrass were seeded by hand in separate $0.5-\mathrm{m}$ rows during October through November, the fall preceding field measurements. We measured plants for one growing season and planted more seeds the following fall. Anatone bluebunch wheatgrass seed was purchased from the Granite Seed Company in Lehi, Utah. The cheatgrass seed planted at Onaqui and Stansbury was hand collected from Skull Valley, Utah, in June 2007, and the cheatgrass seed planted at Greenville was collected from the same area in June 2008. We hand selected individual seeds to ensure that all seeds were filled and likely to germinate. Petri-dish germinability tests resulted in $97 \%$ cheatgrass germination and $100 \%$ bluebunch wheatgrass germination, but in an associated field study using the same seedlots, many of the retrieved seedbags for both species had $100 \%$ germination using 40 seeds per seedbag. Based on this information, we treated the 40 seeds per row as pure live seed. Wire netting with $2.5-\mathrm{cm}$ openings was placed around rows with emerged seedlings at Greenville in 2010 because of higher than usual wildlife browsing.

We measured soil water matric potential in one unamended tree per block in masticated and untreated plots at each study location. The microsites included litter mounds, removed-litter mounds, and bare interspaces in both treatment types plus debris-covered interspaces and debris-covered litter mounds in masticated plots resulting in 32 microsite experimental units per study location.

\section{Field Measurements}

After seeding, we measured the depth of the replaced juniper litter mounds and juniper debris to the nearest $0.5 \mathrm{~cm}$ using a ruler. Seedling emergence, tillers, aboveground biomass, and cheatgrass spikelets were measured at Greenville in 2009 and 2010 and at Onaqui in 2008 and 2009, except tillers were not counted at Onaqui in 2008. Seedling emergence was measured at Stansbury in 2009 and not 2010 because a wildfire in August 2009 ended our study at this location. We counted seedling emergence at approximately 3 -wk intervals during the first spring and early summer following fall seeding. We counted tillers per row during summer before August harvest because many plants became intermingled and indistinguishable as individual plants. Cheatgrass tillers were collected as their seed heads became ripe, but bluebunch wheatgrass did not produce seed the first growing season. We harvested all remaining aboveground biomass within $0.5 \mathrm{~cm}$ of the soil in August and oven dried it at $60^{\circ} \mathrm{C}$ for at least $72 \mathrm{~h}$. When preparing hand-collected cheatgrass seed for fall seeding, we found that the first floret in each spikelet was usually the only filled seed. So, after harvesting planted rows, we counted the number of spikelets per row to represent cheatgrass seed production. To quantify the effects of debris on seedling emergence from the soil, we moved the debris on half of the debris-covered microsites long enough to count seedlings emerged from the soil under the debris. The exception was at Onaqui in 2008 when debris was moved on all debris- covered microsites to count seedling emergence. On the other half of the debris-covered microsites, we counted the number of seedlings that emerged through the debris far enough to be visible without moving the debris.

We measured inorganic $\mathrm{N}$ using plant root simulator (PRS) probes (Western Ag Innovations, Inc, Saskatoon, SK) buried vertically in the top $12 \mathrm{~cm}$ of soil in each microsite. We combined inorganic $\mathrm{N}$ samples from similar microsites of replicated trees within blocks resulting in 56 samples per sampling date at each location. PRS probes were installed and exchanged in March, July, and October through November with probes remaining in the field for 4 mo. Inorganic $\mathrm{N}$ results were summarized across seasons. We measured inorganic $\mathrm{N}$ at Greenville (2009, 2010), Onaqui (2008, 2009), and Stansbury (2009). After collecting PRS probes, we cleaned them with deionized water and returned them to Western Ag Innovations for nitrate and ammonium analysis.

Soil water matric potential was measured with gypsum blocks (Delmhorst Instrument Co, Towaco, NJ) buried at 1-3, 13-15, and 28-30-cm soil depths. We measured soil water potential during spring (1 March-30 June), summer (1 July-31 August), fall (1 September-30 November), and winter (1 December-28 February) at Greenville (2009, 2010), Onaqui (2008-2010), and Stansbury (early 2009). We presented soil water results at 1 - to $3-\mathrm{cm}$ soil depths for spring only because spring is a critical season for seedling establishment. Data loggers (CR10X, Campbell Scientific, Inc, Logan, UT) recorded hourly average electrical resistance from gypsum blocks measured at 1-min intervals. Electrical resistance was converted to soil water potential using a standard calibration curve (Campbell Scientific, Inc, 1983).

\section{Data Analysis}

We analyzed all response variables using mixed-model analysis of variance in Proc Mixed or Glimmix (SAS version 9.2, SAS Institute, Inc, Cary, NC). The maximum likelihood estimation method used for mixed-model analysis of variance resulted in an F-test for testing the significance of fixed effects. Treatments were implemented on different years in a stagger-start design (Loughlin 2006). This design and analysis of all locations and years together extended our inferences beyond an individual location and year. We nested microsites in trees, trees in blocks, blocks in years, and years in locations in the random statement to account for variability associated with treatments being applied and measurements taken on different years at different locations. This nested structure also accounted for potential spatial correlation among microsites.

Masticated plots had more microsite types than untreated plots because of the debris-covered microsites and N-S and Camended microsites in masticated plots. This uneven number of microsite types between treatment plots prevented a full factorial analysis. Instead, we used linear contrasts to compare responses among microsite types within and across treatment plots and between the five masticated and three untreated microsites to quantify the overall treatment effect. To prepare the data for the overall treatment comparison using linear contrasts, we assigned each treatment (trt) by microsite (micro) by amendment (amend) combination to 1 of 20 levels for emergence; 1 of 11 levels for tillers, aboveground biomass, and 
Table 1. Seedling establishment mixed-model analysis of variance with type III F-tests from maximum likelihood estimation. Anatone bluebunch wheatgrass and cheatgrass seedling emergence, tillers, aboveground biomass, and cheatgrass spikelets measured at Greenville in 2009 and 2010 and Onaqui in 2008 and 2009 (Onaqui tillers not counted in 2008). Seedling emergence measured at Stansbury in 2009. Treatment (trt) by microsite (micro) by amendment (amend) combinations assigned to 1 of 20 levels for emergence and 1 of 11 levels for tillers, aboveground biomass, and cheatgrass spikelets.

\begin{tabular}{|c|c|c|c|c|c|}
\hline Response variable & Effect & Num $\mathrm{DF}^{1}$ & Den $\mathrm{DF}^{2}$ & $F$ value & $P$ value \\
\hline \multirow[t]{3}{*}{ Emergence (\%) } & Trt-micro-amend & 19 & 286 & 21.92 & $<0.001$ \\
\hline & Species & 1 & 727 & 55.26 & $<0.001$ \\
\hline & Trt-micro-amend * Species & 19 & 727 & 2.91 & $<0.001$ \\
\hline \multirow[t]{3}{*}{ Tillers (No.) } & Trt-micro-amend & 10 & 109 & 6.71 & $<0.001$ \\
\hline & Species & 1 & 281 & 18.61 & $<0.001$ \\
\hline & Trt-micro-amend * Species & 10 & 281 & 1.07 & 0.389 \\
\hline \multirow[t]{3}{*}{ Aboveground biomass (g) } & Trt-micro-amend & 10 & 122 & 12.65 & $<0.001$ \\
\hline & Species & 1 & 415 & 0.11 & 0.741 \\
\hline & Trt-micro-amend * Species & 10 & 415 & 0.28 & 0.985 \\
\hline Cheatgrass Spikelets (№.) & Trt-micro-amend & 10 & 138 & 10.00 & $<0.001$ \\
\hline
\end{tabular}

${ }^{1}$ Numerator degrees of freedom.

${ }^{2}$ Denominator degrees of freedom.

cheatgrass spikelets; and 1 of 14 levels for inorganic N. An example of a level is unamended bare interspace microsites in masticated plots, and another example is N-S fertilized debriscovered interspaces in masticated plots. The number of levels among seedling establishment response variables differed because the repeated moving and replacing debris on half of the debris-covered microsites to count seedlings emerged from the soil did not allow seedlings to grow through the debris and produce enough tillers, aboveground biomass, or spikelets to analyze. We assigned each treatment by microsite combination for soil water potential to one of eight levels of the trt-micro main effect. We adjusted for multiple comparison falsepositives using pseudo-Bonferroni with a critical alpha level of 0.01 for 60 or fewer comparisons and 0.001 for more than 60 comparisons.

The number of observations for seedling emergence, tiller counts, aboveground biomass, and cheatgrass spikelets were $1120,456,584$, and 292, respectively. Seedling establishment fixed effects included trt-micro-amend and species, and random effects included location, year, block, and tree. Interaction between trt-micro-amend and species allowed us to compare Anatone bluebunch wheatgrass and cheatgrass seedling establishment among microsites. Seedling emergence values did not need to be transformed to meet residuals distribution requirements for analysis of variance based on review of residuals plots. Tiller counts, aboveground biomass, and cheatgrass spikelets were log-transformed prior to analysis and backtransformed by exponentiation for presentation. Soil water potential was summarized as the number of wet days $(>-1.5$ $\mathrm{MPa})$ per season. Wet days did not need to be transformed to meet distribution requirements for analysis of variance. Fixed effects for wet days included trt-micro, season, and sensor depth, and random effects included years, locations, blocks, and trees. Inorganic $\mathrm{N}$ was log-transformed prior to analysis. Fixed effects for inorganic $\mathrm{N}$ included trt-micro-amend and season, and random effects included location, year, block, and tree. For wet days and inorganic N, we accounted for potential temporal correlation using repeated measures in SAS.

\section{RESULTS}

The combined trt-micro-amend main effect was significant for seedling emergence, tillers, aboveground biomass, and spikelets $(P<0.001$; Table 1). The species effect was significant for emergence and tillers $(P<0.001)$. The trt-micro-amend by species interaction was significant for emergence $(P<0.001$; Table 1).

\section{Juniper Tree Mastication Effect}

Unamended masticated plots had fewer but more productive seedlings than untreated plots. For example, bluebunch wheatgrass had $16 \%$ (95\% CI: 11-21) fewer and cheatgrass had $10 \%$ (95\% CI: 5-15) fewer seedlings emerge per row in unamended masticated plots than untreated plots $(P<0.001$; Table 2). However, bluebunch wheatgrass seedlings had 3.2 (95\% CI: 2.0-5.2) times more tillers and 1.9 (95\% CI: 1.6-2.2) times more aboveground biomass per row in unamended masticated plots than untreated plots $(P<0.001$; Figs. 2 and 3). Similarly, cheatgrass had 2.3 (95\% CI: $1.5-3.8)$ times more tillers, 2.0 (95\% CI: 1.7-2.4) times more aboveground biomass, and 11.4 (95\% CI: 6.3-20.7) times more spikelets per row in unamended masticated plots than untreated plots $(P<0.001$; Figs. 2-4). Unamended masticated plots had 4.2 (95\% CI: 3.3-5.3) times more inorganic $\mathrm{N}$ than untreated plots $(P<0.001$; Table 3). Masticated plots had 25.5 (95\% CI: 19.3-31.7) more wet days than untreated plots during spring at the 1 - to 3 -cm soil depth $(P<0.001$; Table 4$)$.

\section{Litter Mound Effect}

Litter mounds had fewer and less productive seedlings than uncovered untreated microsites (Table 2; Figs. 2-4). The average depth for litter mounds was $4.8 \mathrm{~cm}$ (range 0.5-11 cm; Fig. 5). Bluebunch wheatgrass had 17\% (95\% CI: 8-25) more and cheatgrass had 23\% (95\% CI: $14-31$ ) more seedlings emerge per row in bare interspaces than litter mounds in untreated plots $(P<0.001$; Table 2$)$. Bluebunch wheatgrass had 3.2 (95\% CI: 1.5-7.2) times more and cheatgrass had 4.7 
Table 2. Seedling emergence linear-contrast comparisons. Forty seeds of Anatone bluebunch wheatgrass and cheatgrass seeded in separate 0.5 -m rows each fall. Applied ammonium sulfate $\left(\left[\mathrm{NH}_{4}\right]_{2} \mathrm{SO}_{4}\right)$ at $224 \mathrm{~kg} \cdot \mathrm{ha}{ }^{-1} \mathrm{~N}$ and sucrose $\left(\mathrm{C}_{12} \mathrm{H}_{22} \mathrm{O}_{11}\right)$ at $1100 \mathrm{~kg} \cdot \mathrm{ha}{ }^{-1} \mathrm{C}$ each fall. Data collected at Greenville in 2009 and 2010, Onaqui in 2008 and 2009, and Stansbury in 2009.

\begin{tabular}{|c|c|c|c|c|c|}
\hline \multirow[b]{2}{*}{ Microsite } & \multicolumn{2}{|c|}{ Unamended treatment effect } & \multicolumn{3}{|c|}{ Amendment effect in masticated plots } \\
\hline & Untreated & Masticated & Unamended & $\left(\mathrm{NH}_{4}\right)_{2} \mathrm{SO}_{4}$ & $\mathrm{C}_{12} \mathrm{H}_{22} \mathrm{O}_{11}$ \\
\hline Bluebunch wheatgrass & \multicolumn{2}{|c|}{---------------- \%----------------- } & --------------- & $----\%$------. & -----------. \\
\hline Litter mound & $33^{1} b^{2}$ & $36 \mathrm{~b}$ & - & - & - \\
\hline Removed-litter mound & $53^{3} \mathrm{a}$ & $37 \mathrm{~b}$ & - & - & - \\
\hline Bare interspace & $50^{3} \mathrm{a}$ & $37 \mathrm{~b}$ & 37 & $34 \mathrm{a}$ & $31 \mathrm{~b}$ \\
\hline Moved debris-covered litter mound & - & $22 b c$ & 22 & $17 \mathrm{~b}$ & $14 \mathrm{bc}$ \\
\hline Unmoved debris-covered litter mound & - & $4 \mathrm{c}$ & 4 & $3 \mathrm{~b}$ & $3 c$ \\
\hline Moved debris-covered interspaces & - & $56 \mathrm{a}$ & 56 & $42^{4} \mathrm{a}$ & $57 \mathrm{a}$ \\
\hline \multirow[t]{2}{*}{ Unmoved debris-covered interspaces } & - & $12 \mathrm{c}$ & 12 & $13 b$ & $23 \mathrm{bc}$ \\
\hline & $45^{5}$ & 29 & 26 & 22 & 26 \\
\hline \multicolumn{6}{|l|}{ Cheatgrass } \\
\hline Litter mound & $16 \mathrm{~b}$ & $22 \mathrm{ab}$ & - & - & - \\
\hline Removed-litter mound & $46 \mathrm{a}$ & $43 \mathrm{a}$ & - & - & - \\
\hline Bare interspace & 39 a & $33 \mathrm{a}$ & 33 & $36 \mathrm{a}$ & $28 a b$ \\
\hline Moved debris-covered litter mound & - & 12 bc & 12 & $9 \mathrm{c}$ & $6 \mathrm{c}$ \\
\hline Unmoved debris-covered litter mound & - & $3 c$ & 3 & $1 \mathrm{c}$ & $1 \mathrm{c}$ \\
\hline Moved debris-covered interspaces & - & $42 \mathrm{a}$ & 42 & $27^{4} \mathrm{ab}$ & $42 \mathrm{a}$ \\
\hline \multirow[t]{2}{*}{ Unmoved debris-covered interspaces } & - & $7 \mathrm{bc}$ & 7 & $9 \mathrm{bc}$ & $14 \mathrm{bc}$ \\
\hline & $33^{5}$ & 23 & 19 & 16 & 18 \\
\hline
\end{tabular}

${ }^{1}$ Species differences within columns are italicized $(P<0.01)$.

${ }^{2}$ Microsite differences within columns and species have different letters $(P<0.01)$.

${ }^{3}$ Removed-litter mounds and bare interspaces for bluebunch wheatgrass, untreated $>$ unamended masticated $(P<0.01)$.

${ }^{4}$ Moved debris-covered interspaces for bluebunch wheatgrass and cheatgrass, sucrose $>$ ammonium sulfate; cheatgrass, unamended $>$ ammonium sulfate $(P<0.01)$.

${ }^{5}$ Bluebunch wheatgrass and cheatgrass collectively, untreated $>$ unamended masticated $(P<0.01)$.

(95\% CI: 2.1-10.3) times more tillers per row, and cheatgrass had 4.4 (95\% CI: 1.6-12.3) times more spikelets per row in bare interspaces than litter mounds $(P<0.01$; Figs. 2 and 4$)$. Following the same pattern, removed-litter mounds had more seedlings and tillers per row than litter mounds in untreated plots (Table 2; Fig. 2). However, in masticated plots, litter mounds had little effect on seedling establishment in unamended microsites (Table 2; Figs. 2-4). Bluebunch wheatgrass and cheatgrass emergence, tiller counts, and aboveground biomass and cheatgrass spikelets were not different among litter mounds, removed-litter mounds, or bare interspaces except that bluebunch wheatgrass had 1.4 (95\% CI: 1.1-1.9) times more aboveground biomass per row in litter mounds than bare interspaces in masticated plots $(P<0.01$; Table 2; Figs. 2-4). Bare interspaces had 1.9 (95\% CI: 1.3-3.0) times more inorganic $\mathrm{N}$ than litter mounds in untreated plots, but in unamended masticated microsites, litter mounds had 1.9 (95\% CI: 1.2-2.9) times more inorganic $\mathrm{N}$ than bare interspaces across seasons $(P<0.01$; Table 3$)$. Also in masticated plots, litter mounds had 28.5 (95\% CI: 17.3-39.7) more wet days than bare interspaces during spring at the $1-$ to $3-\mathrm{cm}$ soil depth $(P<0.001)$, but in untreated plots, litter mounds and bare interspaces had a similar number of wet days $(P>0.001$; Table 4).

\section{Debris Effect}

Unamended debris increased seedling emergence from the soil but decreased seedling emergence through the debris (Table 2). The average debris depth for debris-covered interspaces was
$6.3 \mathrm{~cm}$ (range 1.5-13.5 cm; Fig. 5), and the average combined debris and litter mound depth for debris-covered litter mounds was $10.7 \mathrm{~cm}$ (range 5-19 cm). In debris-covered interspaces where the debris was repeatedly moved during spring to count emerged seedlings, bluebunch wheatgrass had 19\% (95\% CI: 9-29) more seedlings emerge than in bare interspaces even though cheatgrass emergence was not significantly different across these microsites $(P>0.001$; Table 2$)$. However, in debris-covered interspaces where the debris was not moved and seedlings had to emerge through the debris to be counted, bluebunch wheatgrass had 25\% (95\% CI: 14-37) fewer and cheatgrass had 27\% (95\% CI: 15-38) fewer seedlings emerge than in bare interspaces $(P>0.001$; Table 2$)$. The movement of debris to count seedling emergence in moved debris-covered microsites and the combined layers of debris and litter in debris-covered litter mounds prevented sufficient seedling survival for collection and analysis of aboveground biomass, tillers, and spikelets. Debris in unmoved debris-covered microsites did not change bluebunch wheatgrass or cheatgrass tillers, aboveground biomass, or spikelets compared to the other masticated microsites (adjusted $P>0.01$; Figs. 2-4). Seedling establishment patterns among N-S and C-amended microsites were similar to unamended microsites. Unamended bare interspaces had 2.2 (95\% CI: 1.4-3.4) times more inorganic $\mathrm{N}$ than debris-covered interspaces $(P<0.01$; Table 3). Debris-covered interspaces had 31.4 (95\% CI: 20.1-42.7) more and debris-covered litter mounds had 35.0 (95\% CI: 23.8-46.2) more wet days than bare interspaces during spring at the 1 - to $3-\mathrm{cm}$ soil depth $(P<0.001$; Table 4$)$. 


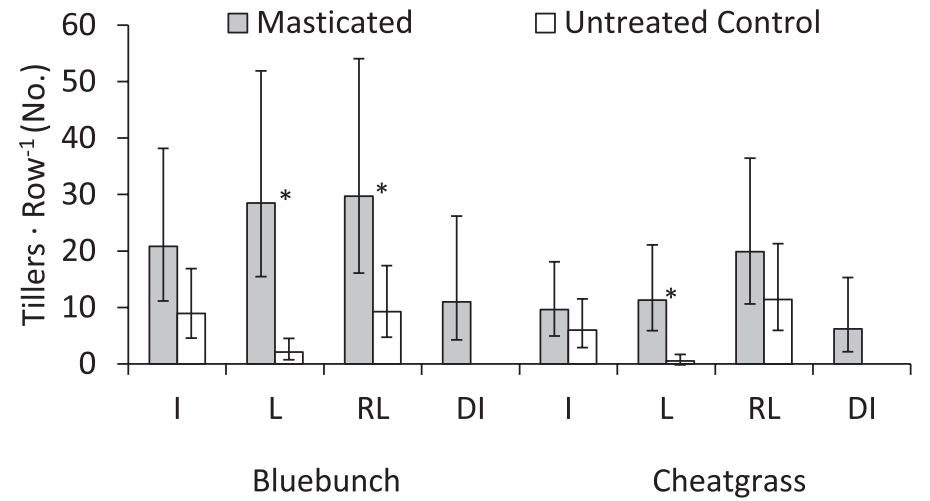

Figure 2. Tillers per row compared between unamended masticated and untreated microsites. Forty seeds of Anatone bluebunch wheatgrass and cheatgrass seeded in separate 0.5-m rows each fall. Error bars are 95\% confidence intervals. Asterisks indicate microsite differences $(P<0.01)$. I indicates bare interspaces; L, litter mounds; RL, removed-litter mounds; and $\mathrm{DI}$, debris-covered interspaces without moving debris to count emergence. Data collected at Greenville in 2009 and 2010 and Onaqui in 2009.

\section{Species Effect}

Bluebunch wheatgrass had 12\% (95\% CI: 8-16) more seedlings emerge per row than cheatgrass across all untreated microsites $(P<0.01$; Table 2$)$. Likewise, bluebunch wheatgrass had 6\% (95\% CI: 3-9) more seedlings emerge per row than cheatgrass across all microsites in unamended masticated plots with a similar pattern among $\mathrm{N}-\mathrm{S}$ and C-amended microsites $(P<0.01$; Table 2$)$. Bluebunch wheatgrass seedling emergence was notably higher than cheatgrass in litter mounds of both untreated and unamended masticated plots. Consistent with these results, bluebunch wheatgrass had 1.9 (95\% CI: 1.3-2.6) times more tillers per row across microsites and 2.4 (95\% CI: 1.3-4.3) times more tillers per row in litter mounds than cheatgrass in unamended masticated plots $(P<0.01$; Fig. 2). Aboveground biomass was not different between species with any microsite comparison $(P>0.01$; Fig. 2$)$.

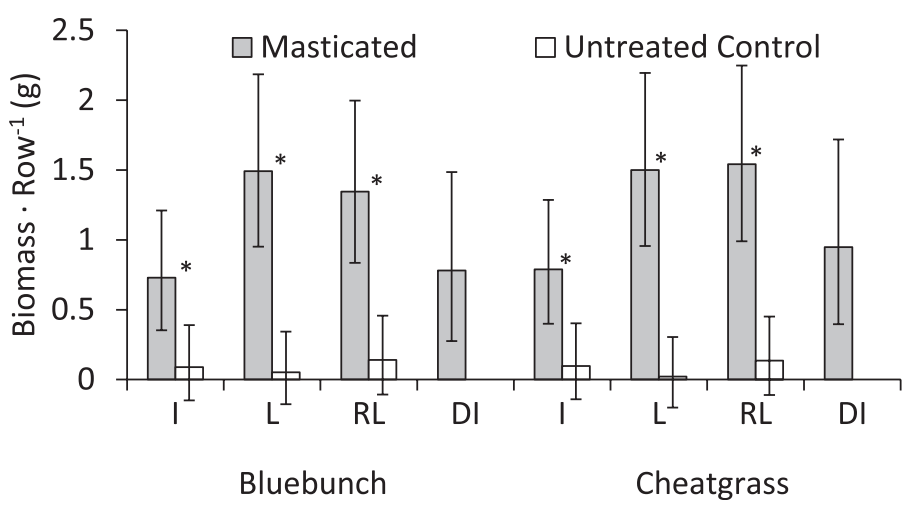

Figure 3. Aboveground biomass per row compared between unamended masticated and untreated microsites. Forty seeds of Anatone bluebunch wheatgrass and cheatgrass seeded in separate $0.5-\mathrm{m}$ rows each fall. Error bars are 95\% confidence intervals. Asterisks indicate microsite differences $(P<0.01)$. I indicates bare interspaces; $L$, litter mounds; $R L$, removed-litter mounds; and $\mathrm{DI}$, debris-covered interspaces without moving debris to count emergence. Data collected at Greenville in 2009 and 2010 and Onaqui in 2008 and 2009.

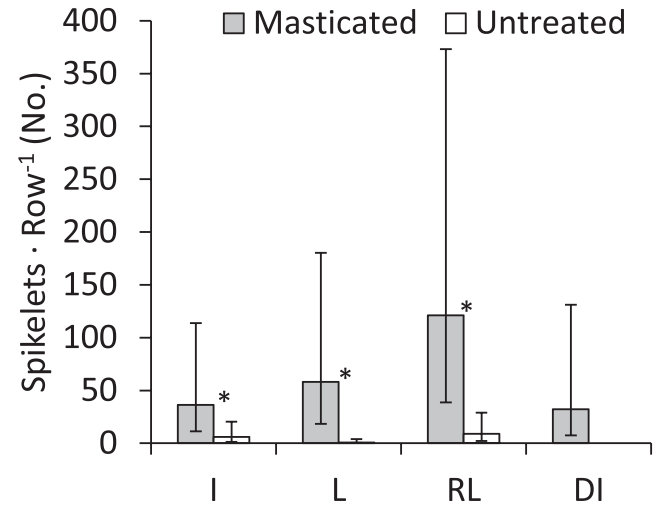

Figure 4. Cheatgrass spikelets per row compared between unamended masticated and untreated control microsites. Forty seeds of Anatone bluebunch wheatgrass and cheatgrass seeded in separate $0.5-\mathrm{m}$ rows each fall. Error bars are 95\% confidence intervals. Asterisks indicate microsite differences $(P<0.01)$. I indicates bare interspaces; L, litter mounds; RL, removed-litter mounds; and DI, debris-covered interspaces without moving debris to count emergence. Data collected at Greenville in 2009 and 2010 and Onaqui in 2008 and 2009.

\section{Soil Amendment Effect}

Bluebunch wheatgrass and cheatgrass in moved debris-covered interspaces had $15 \%$ (95\% CI: 4-26) more seedlings emerge from the soil in $\mathrm{C}$ than N-S microsites in masticated plots $(P<0.01$; Table 2). Bare interspaces and unmoved debriscovered interspaces collectively had 1.5 (95\% CI: $1.1-2.0)$ times more cheatgrass aboveground biomass per row in unamended than $\mathrm{C}$ microsites $(P<0.01$; Fig. 6). No amendment effect was found for bluebunch wheatgrass tillers or cheatgrass tillers and spikelets $(P>0.01$; data not shown). Bare and debris-covered interspaces and debris-covered litter mounds fertilized with N-S collectively had $3.5 \quad(95 \%$ CI: 2.7-4.5) times more inorganic $\mathrm{N}$ than unamended microsites and $8.6(95 \%$ CI: 6.7-11.0) times more inorganic $\mathrm{N}$ than sucrose microsites $(P<0.01$; Table 3$)$. Unamended microsites had 2.5 (95\% CI: 1.9-3.2) times more inorganic $\mathrm{N}$ than sucrose microsites $(P<0.01$; Table 3$)$.

\section{DISCUSSION}

Juniper Mastication Effect

Masticated areas generally had fewer bluebunch wheatgrass and cheatgrass seedlings emerge than untreated areas. This was likely due to increased cover from masticated-juniper debris. While thin soil cover can increase emergence by reducing evaporative water loss, thick cover can physically impede seedling emergence and intercept light and precipitation necessary for germination and establishment (Facelli and Pickett 1991). The point where cover depth transitions from helping to hindering seedling establishment varies by environmental context. Different locations have different rainfall durations and intensities that influence the percent rainfall intercepted by cover (Facelli and Pickett 1991). Different cover types have different capacities for adsorbing precipitation, different bulk densities, and different shapes and sizes that can physically impede seedling emergence to varying degrees 
Table 3. Soil inorganic $\mathrm{N}\left(\mathrm{NO}_{3}+\mathrm{NH}_{4}\right)$ linear-contrast comparisons from plant root simulator (PRS) probes in top $12 \mathrm{~cm}$ of soil for 4 mo. Applied ammonium sulfate $\left(\left[\mathrm{NH}_{4}\right]_{2} \mathrm{SO}_{4}\right)$ at $224 \mathrm{~kg} \cdot \mathrm{ha}^{-1} \mathrm{~N}$ and sucrose $\left(\mathrm{C}_{12} \mathrm{H}_{22} \mathrm{O}_{11}\right)$ at $1100 \mathrm{~kg} \cdot \mathrm{ha}^{-1} \mathrm{C}$ each fall. Data collected at Greenville in 2009 and 2010 , Onaqui in 2008 and 2009, and Stansbury in 2009.

\begin{tabular}{|c|c|c|c|c|c|}
\hline \multirow[b]{2}{*}{ Microsite } & \multicolumn{2}{|c|}{ Unamended treatment effect } & \multicolumn{3}{|c|}{ Amendment effect in masticated plots } \\
\hline & Untreated & Masticated & Unamended & $\left(\mathrm{NH}_{4}\right)_{2} \mathrm{SO}_{4}$ & $\mathrm{C}_{12} \mathrm{H}_{22} \mathrm{O}_{11}$ \\
\hline & \multicolumn{2}{|c|}{ - } & --------------. & $m^{-2} \cdot 4 m o^{-}$ & -------- \\
\hline Litter mound & $38^{1} \mathrm{~b}^{2}$ & $377 \mathrm{a}$ & - & - & - \\
\hline Removed-litter mound & $81 \mathrm{a}$ & 477 a & - & - & - \\
\hline Bare interspace & $75 \mathrm{a}$ & $197 \mathrm{~b}$ & $197 \mathrm{~b}$ & $744^{3} \mathrm{a}$ & $33^{4} \mathrm{~b}$ \\
\hline Debris-covered interspace & - & $89 \mathrm{c}$ & $89 \mathrm{c}$ & $544 \mathrm{a}$ & $33^{4} \mathrm{~b}$ \\
\hline \multirow[t]{2}{*}{ Debris-covered litter mound } & - & 380 a & 380 a & 687 a & 379 a \\
\hline & 65 & 304 & 222 & $658^{3}$ & $148^{5}$ \\
\hline
\end{tabular}

${ }^{1}$ Individually and collectively, unamended masticated $>$ untreated $(P<0.01)$.

${ }^{2}$ Microsite differences within columns have different letters $(P<0.01)$.

${ }^{3}$ Individually and collectively, ammonium sulfate $>$ unamended and sucrose $(P<0.01)$.

${ }^{4}$ Bare and debris-covered interspaces, sucrose $<$ unamended $(P<0.01)$.

${ }^{5}$ Collectively, sucrose $<$ unamended $(P<0.01)$.

(Facelli and Pickett 1991). While one study suggested that $5 \mathrm{~cm}$ or deeper of chipped Utah juniper and single-leaf piñon (Pinus monophylla Torr. and Frem.) reduces seedling emergence (Benson 2006), our data suggested that seedling emergence gradually declines with increased juniper debris cover. However, the bluebunch wheatgrass and cheatgrass seedlings that did emerge in masticated areas had more aboveground biomass and tillers, and cheatgrass had more spikelets than untreated areas supporting our first hypothesis that juniper tree mastication would increase seedling establishment. The increased growth of both bluebunch wheatgrass and cheatgrass was likely associated with greater soil inorganic N, more wet days, and warmer soil temperatures in masticated areas (Young 2012), which suggests that both species when present will increase following juniper mastication.

\section{Litter Mound Effect}

Litter mounds had less bluebunch wheatgrass and cheatgrass emergence, tillers, and cheatgrass spikelets than removed-litter mounds and interspaces in untreated areas. This lower seedling establishment was likely associated with less inorganic $\mathrm{N}$, greater competition from juniper roots (Emerson 1932), and physical impedance of seedling emergence by litter mounds (Facelli and Pickett 1991; Horman and Anderson 2003). However, juniper mastication changed the plant establishment

Table 4. Wet day linear-contrast comparisons during spring (1 March-30 June) at 1- to 3-cm soil depth. Data measured at Greenville in 2009 and 2010, Onaqui in 2008 and 2009, and Stansbury in 2009 using gypsum blocks.

\begin{tabular}{lcc}
\hline \multicolumn{1}{c}{ Microsite } & Untreated & Masticated \\
\hline Litter mound & $91 \mathrm{a}^{1}$ & $114^{2} \mathrm{a}$ \\
Removed-litter mound & $67 \mathrm{~b}$ & $86^{2} \mathrm{~b}$ \\
Bare interspace & $81 \mathrm{ab}$ & $86 \mathrm{~b}$ \\
Debris-covered interspace & & $117 \mathrm{a}$ \\
Debris-covered litter mound & & $121 \mathrm{a}$ \\
& 80 & 105 \\
\hline
\end{tabular}

${ }^{1}$ Treatment differences are italicized $(P<0.001)$.

${ }^{2}$ Microsite differences within columns have different letters $(P<0.01)$. pattern among microsites from that of untreated areas. Litter mounds had little effect on seedling establishment in masticated areas even though litter mounds had more soil inorganic $\mathrm{N}$ than bare interspaces, as expected of resource islands (Brotherson and Osayande 1980; Padien and Lajtha 1992). This result is contrary to our second hypothesis that higher soil inorganic $\mathrm{N}$ in litter mounds would favor cheatgrass establishment although with more time since treatment the cheatgrass response could change. The greater soil inorganic $\mathrm{N}$ in litter mounds of masticated areas was also likely associated with increased soil nutrient diffusion as a result of longer periods of available soil water (Leffler and Ryel 2012) after juniper trees were masticated and no longer using resources. These improved environmental conditions probably compensated for some of the physical impedance of seedling emergence by litter mounds resulting in similar seedling establishment between litter mounds and bare interspaces.

Our results are applicable to seedling establishment from seeds in the soil, but in natural settings seeds end up in a variety of locations that may be less optimal. Species with winddispersed seeds capable of establishing inside plant litter may initially dominate litter mounds following juniper mastication. For example, we observed unplanted cheatgrass seedlings with leaves growing above litter mounds and their seeds suspended in the litter with roots extending down into the soil. This demonstrates both the exceptional ability of cheatgrass to establish and litter mounds to provide environmental conditions suitable for vigorously establishing species. Others studies have also found litter mounds to provide favorable conditions for cheatgrass establishment (Young and Evans 1975; Evans and Young 1984; Chambers et al. 2007). The ability of cheatgrass to establish with its seed suspended in litter mounds appears to have given it access to the greater soil $\mathrm{N}$ and water we found below litter mounds. This establishment ability could enable cheatgrass to "perceive" a larger resource pool than that perceived by less vigorously establishing species, and may allow cheatgrass to reduce the size of the resource pool available to slower establishing species (Leffler and Ryel 2012). This access to greater resource availability could provide an avenue for cheatgrass to invade plant communities where it was previously a minor component; an example of the fluctuating resource 

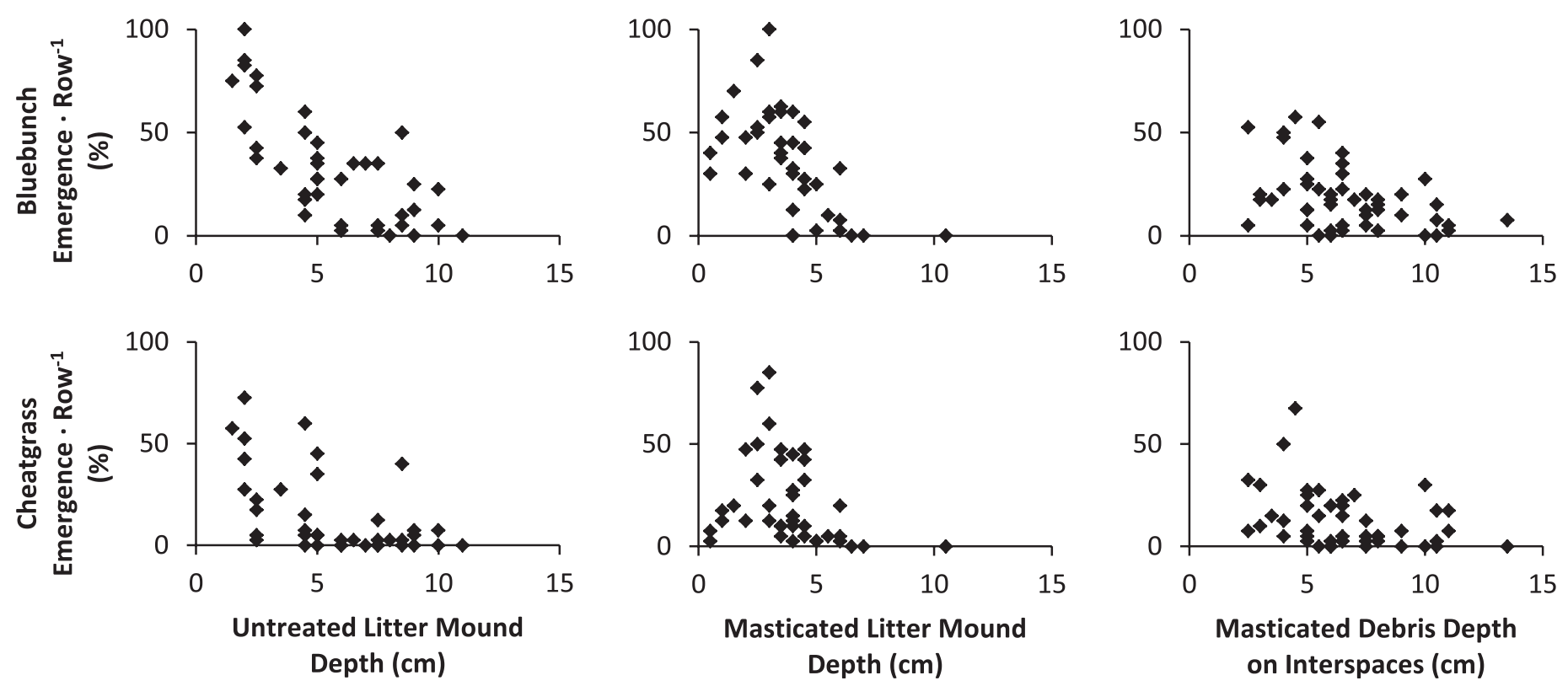

Figure 5. Seedling emergence and surface cover depths for juniper litter mounds and masticated debris-covered interspaces.

hypothesis where increased resource availability leads to increased plant community invasibility (Davis et al. 2000).

\section{Debris Effect}

More bluebunch wheatgrass seedlings emerged from the soil under debris in moved debris-covered interspaces than bare interspaces in masticated areas. This result was associated with more moisture under debris during spring, but the additional water was not enough to enable many seedlings to grow through the physical barrier of unmoved debris. However, the few seedlings that did emerge through unmoved debris produced as much biomass and as many tillers and spikelets per row as seedlings growing in bare interspaces. This increased growth per plant was probably due to the greater soil water

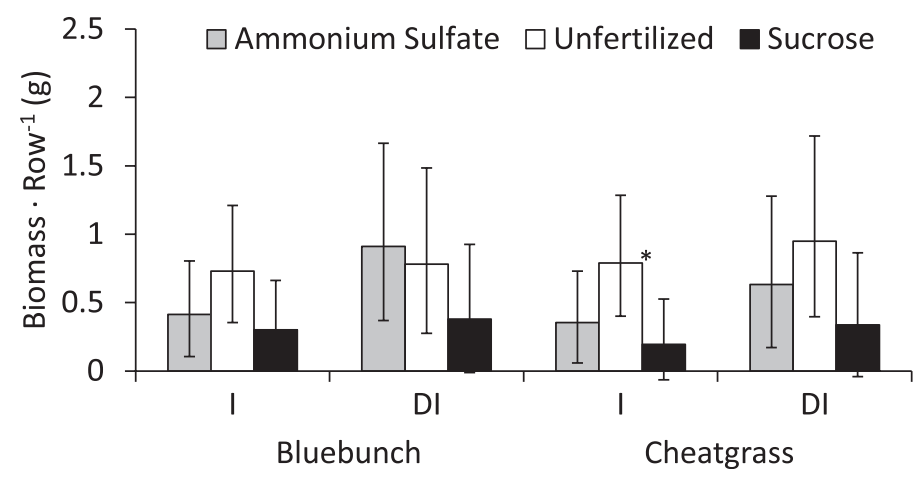

Figure 6. Seedling aboveground biomass per row compared among masticated and amended microsites. Forty seeds of Anatone bluebunch wheatgrass and cheatgrass seeded in separate 0.5 -m rows each fall. Error bars are $95 \%$ confidence intervals. Applied ammonium sulfate $\left(\left[\mathrm{NH}_{4}\right]_{2} \mathrm{SO}_{4}\right)$ at $224 \mathrm{~kg} \cdot \mathrm{ha}^{-1} \mathrm{~N}$ and sucrose $\left(\mathrm{C}_{12} \mathrm{H}_{22} \mathrm{O}_{11}\right)$ at $1100 \mathrm{~kg} \cdot \mathrm{ha}^{-1} \mathrm{C}$ once each fall. Asterisks indicate amendment differences $(P<0.01)$. I indicates bare interspaces; DI, debris-covered interspaces without moving debris to count emergence. Data collected at Greenville in 2009 and 2010 and Onaqui in 2008 and 2009. availability in debris-covered interspaces during spring rather than soil inorganic $\mathrm{N}$ because there was less soil inorganic $\mathrm{N}$ in debris-covered interspaces than bare interspaces. These results indicate that water is more limiting of seedling establishment than soil inorganic $\mathrm{N}$ in these ecosystems and support earlier work that found soil water availability to be the primary determinant of seedling establishment in similar areas (Chambers et al. 2007). The overall similarity in seedling establishment between both species suggests that debris will not favor bluebunch wheatgrass establishment over cheatgrass as we had speculated.

\section{Species Effect}

Bluebunch wheatgrass had more seedlings in masticated and untreated areas and more tillers in masticated areas than cheatgrass even though most establishment measurements were similar between species. The greater bluebunch wheatgrass emergence and number of tillers were associated with the strong establishment characteristics of the naturally selected Anatone population of bluebunch wheatgrass. Anatone was selected in part for its fast germination rate at cold temperatures and strong seedling emergence, establishment, and vigor; traits that help Anatone compete with invasive annuals like cheatgrass (Monsen et al. 2003). These characteristics and our results suggest that Anatone, where adapted, would be a good choice when seeding perennial grasses in rangeland restoration projects. However, Anatone should not be expected to outcompete cheatgrass at the seedling stage. Even though cheatgrass sometimes had fewer seedlings per row than bluebunch wheatgrass, it produced similar amounts of aboveground biomass. This result indicates that cheatgrass produced more aboveground biomass per plant than bluebunch wheatgrass during the first growing season as has been found in earlier work (James et al. 2011). Cheatgrass and other invasive annuals have high relative growth rates and specific leaf areas that allow them to compete for resources in both high and low nutrient conditions (James 2012). In addition, cheatgrass 
produced seed the first growing season following seeding as is typical of annuals, whereas Anatone did not produce seed until the second growing season. This suggests that if perennial grasses have been severely weakened or lost over decades of juniper dominance, and cheatgrass is prevalent on the project site, cheatgrass will need to be controlled to allow time and resources for seeded perennials such as Anatone to establish.

\section{Soil Amendment Effect}

We hypothesized that $\mathrm{N}$ fertilization would increase cheatgrass establishment and growth over bluebunch wheatgrass and that soil C amendments would increase bluebunch wheatgrass establishment over cheatgrass because of the highly responsive nature of invasive annuals to soil $\mathrm{N}$ availability (Monaco et al. 2003; Mazzola et al. 2011). However, we found that N-S and C amendments had little effect on seedling establishment and first year growth even though N-S fertilization increased soil inorganic $\mathrm{N}$ by two to four times the increase in soil inorganic $\mathrm{N}$ resulting from juniper mastication. The lack of seedling response to increased soil inorganic $\mathrm{N}$ and the similarity in responses between cheatgrass and bluebunch wheatgrass to decreased $\mathrm{N}$ suggest that changes in soil inorganic $\mathrm{N}$ induced by juniper mastication are not sufficient to favor one species over the other, at least when both species are seedlings. However, managing for low nutrient availability should help maintain perennial grass dominance in spite of greater invasive annual growth rates because mature (at least 2-yr old) perennial grasses use nutrients more efficiently (James 2012). Mature perennial grasses resorb nutrients from senescing leaves resulting in longer mean residence time, develop tougher tissues that minimize tissue loss during drought, build greater root:shoot ratios, and maintain structural components avoiding the cost of rebuilding them each year compared to annuals (Monaco et al. 2003; James 2012). From a management perspective, this implies that it would be more efficient to treat juniper encroachment before desirable perennial grasses are greatly reduced.

\section{IMPLICATIONS}

Mastication is useful in a variety of settings but especially in wildland urban interfaces where it can reduce both the degrading effects of juniper encroachment on the historic plant community and the threat of crown fire to nearby communities. Juniper trees should be treated before infilling weakens or depletes perennial grasses. Bluebunch wheatgrass and cheatgrass, if present, are both expected to increase following juniper mastication because of increased soil water and inorganic N. In line with plant community resilience and resistance theory (D'Antonio et al. 2009), we expect areas with dominant perennial grass cover before juniper mastication to have a strong perennial grass component after mastication. If perennial grasses have been lost during decades of juniper dominance, then vigorous perennial grasses like Anatone bluebunch wheatgrass need to be sown. Dominant invasive annuals like cheatgrass with their faster growth rates may need to be controlled (e.g., selective herbicides) to allow slower growing perennial grasses to establish because reducing soil inorganic $\mathrm{N}$ alone during the seedling phase does not enable bluebunch wheatgrass to outcompete cheatgrass (James 2012). Another reason reduced soil inorganic $\mathrm{N}$ did not enable bluebunch wheatgrass to outcompete cheatgrass at the seedling phase could be that water, required for soil nutrient diffusion, limited seedling establishment more than soil inorganic $\mathrm{N}$ in these sagebrush-bunchgrass ecosystems. Once perennials are established, maintaining low soil nutrient availability will help mature perennial grasses that have nutrient-conserving structures compete with invasive annuals (James 2012). Maintaining healthy perennial vegetation before weedy species dominate may be the most effective way to limit invasive annual plant dominance (Chambers et al. 2007; Roundy et al. 2007). Additionally, our results suggest that if litter mounds and masticated debris were spread thin during the mastication treatment that seedling establishment of both grasses would increase.

\section{ACKNOWLEDGMENTS}

We thank the USDI Bureau of Land Management and USDA Forest Service in Utah for helping implement treatments and allowing this research on public lands. We are grateful to the research site managers, April Hulet and Brad Jessop, and the several students who helped with field work. The authors thank the reviewers for constructive comments that helped improve the content of this article.

\section{LITERATURE CITED}

Barney, M. A., AND N. C. FrisChKNeCht. 1974. Vegetation changes following fire in the pinyon-juniper type of west-central Utah. Journal of Range Management 27:9196.

Bates, J. D., R. F. Miller, and T. J. Svejcar. 2000. Understory dynamics in cut and uncut western juniper woodlands. Journal of Range Management 53:119-126.

Beckstead, J., And C. K. Augspurger. 2004. An experimental test of resistance to cheatgrass invasion: limiting resources at different life stages. Biological Invasions 6:417-432.

Benson, T. L. 2006. Understory vegetation responses to pinyon-juniper tree removal, seeding, and chip application, Lincoln County, Nevada [thesis]. Reno, NV, USA: University of Nevada. $114 \mathrm{p}$.

Brady, N. C., AND R. R. Well. 1999. The nature and properties of soils. 12th ed. Upper Saddle River, NJ, USA: Prentice-Hall, Inc. 881 p.

Brotherson, J. D., and S. T. Osayande. 1980. Mineral concentrations in true mountain mahogany and Utah juniper, and in associated soils. Journal of Range Management 33:182-185.

Burkhardt, J. W., and E. W. Tisdale. 1976. Causes of juniper invasion in southwestern Idaho. Ecology 57:472-474.

Chambers, J. C., S. E. Meyer, A. Whittaker, B. A. Roundy, and R. R. Blank. 2007. What makes Great Basin sagebrush ecosystems invasible by Bromus tectorum? Ecological Monographs 77:117-145.

D’Antonio, C. M., J. C. Chambers, R. Loh, and J. T. Tunison. 2009. Applying ecological concepts to the management of widespread grass invasions. In: R. L. Inderjit [ED.]. Applying ecological concepts to the management of widespread grass invasions. Dordrecht, Netherlands: Springer. p. 123-149.

Davis, M. A., J. P. Grime, and K. Thompson. 2000. Fluctuating resources in plant communities: a general theory of invasibility. Journal of Ecology 88:528-534.

EMERSON, F. W. 1932. The tension zone between the grama grass and piñon-juniper associations in northeastern New Mexico. Ecology 13:347-358.

Evans, R. A., and J. A. Young. 1984. Microsite requirements for downy brome (Bromus tectorum) infestation and control on sagebrush rangelands. Weed Science 32:13-17.

Facell, J. M., And S. T. A. Pickett. 1991. Plant litter: its dynamics and effects on plant community structure. Botanical Review 57:1-32. 
Grime, J. P., And R. Hunt. 1975. Relative growth-rate: its range and adaptive significance in a local flora. Journal of Ecology 63:393-422.

Hardegree, S. P., G. N. Flerchinger, and S. S. van Vactor. 2003. Hydrothermal germination response and the development of probabilistic germination profiles. Ecological Modeling 167:305-322.

HarRIS, G. A. 1967. Some competitive relationships between Agropyron spicatum and Bromus tectorum. Ecological Monographs 37:89-111.

Horman, C. S., AND V. J. Anderson. 2003. Understory species response to Utah juniper litter. Journal of Range Management 56:68-71.

JAMES, J. J. 2012. Species performance: the relationship between nutrient availability, life history traits, and stress. In: T. A. Monaco and R. L. Sheley [EDS.]. Invasive plant ecology and management: linking processes to practice. Cambridge, MA, USA: CABI. p. 142-153.

James, J. J., R. E. Drenovsky, T. A. Monaco, and M. J. Rinella. 2011. Managing soil nitrogen to restore annual grass-infested plant communities: effective strategy or incomplete framework? Ecological Applications 21:490-502.

Kane, J. M., J. M. Varner, E. E. Knapp, and R. F. Powers. 2010. Understory vegetation response to mechanical mastication and other fuels treatments in a ponderosa pine forest. Applied Vegetation Science 13:207-220.

KonIAK, S. 1985. Succession in pinyon-juniper woodlands following wildfire in the Great Basin. Great Basin Naturalist 45:556-566.

LefFler, A. J., And R. J. Ryel. 2012. Resource pool dynamics: conditions that regulate species interactions and dominance. In: T. A. Monaco and R. L. Sheley [EDS.]. Invasive plant ecology and management: linking processes to practice. Cambridge, MA, USA: CABI. p. 57-78.

LoughLIN, T. 2006. Improved experimental design and analysis for long-term experiments. Crop Science 46:2492-2506.

Mazzola, M. B., J. C. Chambers, R. R. Blank, D. A. Pyke, E. W. Schupp, K. G. Allcock, P. S. DoESCHER, AND R. S. Nowak. 2011. Effects of resource availability and propagule supply on native species recruitment in sagebrush ecosystems invaded by Bromus tectorum. Biological Invasions 13:513-526.

Mclver, J. D., M. Brunson, And S. C. Bunting. 2010. The sagebrush steppe treatment evaluation project (SageSTEP): a test of state-and-transition theory. Fort Collins, CO, USA: US Forest Service. RMRS-GTR-237. $16 \mathrm{p}$.

Melgoza, G., R. S. Nowak, and R. J. Tausch. 1990. Soil water exploitation after fire: competition between Bromus tectorum (cheatgrass) and two native species. Oecologia 83:7-13.

Mlleer, R. F., J. D. Bates, T. J. Svejcar, F. B. Pierson, and L. E. Eddleman. 2005. Biology, ecology, and management of western juniper. Corvallis, OR, USA: Oregon State University Agricultural Experiment Station. Technical Bulletin 152. $77 \mathrm{p}$.

MilleR, R. F., AND J. R. Rose. 1999. Fire history and western juniper encroachment in sagebrush steppe. Journal of Range Management 52:550-559.

Mlller, R. F., And R. J. TAusch. 2001. The role of fire in pinyon and juniper woodlands: a descriptive analysis. In: K. E. M. Galley and T. P. Wilson [EDS.]. Proceedings of the Invasive Species Workshop: The role of fire in the control and spread of invasive species. Fire Conference 2000. Tallahassee, FL, USA: Tall Timbers Research Station. Miscellaneous Publication 11. p. 15-30.

Monaco, T. A., D. A. Johnson, J. M. Norton, T. A. Jones, K. J. Connors, J. B. Norton, and M. G. ReDinBaugh. 2003. Contrasting responses of intermountain west grasses of soil nitrogen. Journal of Range Management 56:282-290.

Monsen, S. B., S. G. Kitchen, K. Memmott, N. Shaw, M. Pellant, S. Young, D. Ogle, and L. St. JoHn. 2003. Notice to release Anatone germplasm bluebunch wheatgrass (selected class natural population). Provo, UT, USA: US Forest service Rocky Mountain Research Station, Shrub Sciences Laboratory. $45 \mathrm{p}$.

Newman, B. D., M. O. Gard, and D. D. Breshears. 2010. Evapotranspiration partitioning in a semiarid woodland: ecohydrologic heterogeneity and connectivity of vegetation patches. Vadose Zone Journal 9:561-572.

Padien, D. J., and K. LaJtha. 1992. Plant spatial pattern and nutrient distribution in pinyon-juniper woodlands along an elevational gradient in northern New Mexico. International Journal of Plant Sciences 153:425-433.

Paschke, M. W., T. McLendon, and E. F. Redente. 2000. Nitrogen availability and oldfield succession in a shortgrass steppe. Ecosystems 3:144-158.

PRISM Climate Group. 2008. Parameter-elevation regression on independent slopes model. Available at: http://prism.oregonstate.edu. Accessed February 2008.

Rau, B. M., D. W. Johnson, R. R. Blank, R. J. Tausch, B. A. Roundy, R. F. Miller, T. G. CaldWELL, ANd A. LucCheSI. 2011. Woodland expansion's influence on belowground carbon and nitrogen in the Great Basin U.S. Journal of Arid Environments 75:827-835

Rhoades, C. C., M. A. Battaglia, M. E. Rocca, and M. G. Ryan. 2012. Short- and medium-term effects of fuel reduction mulch treatments on soil nitrogen availability in Colorado conifer forests. Forest Ecology and Management 276:231-238.

Roundy, B. A., A. Whittaker, J. C. Chambers, and S. P. Hardegree. 2007. Prediction of cheatgrass field germination potential using wet thermal accumulation. Rangeland Ecology \& Management 60:613-623.

Schlesinger, W. H., and A. M. Pilmanis. 1998. Plant-soil interactions in deserts. Biogeochemistry 42:169-187.

Sylvia, D. M., J. J. Fuhrmann, P. G. Hartel, and D. A. Zuberer. 2005. Principles and applications of soil microbiology. 2nd ed. Upper Saddle River, NJ, USA: Pearson Education, Inc. 607 p.

TAusch, R. J., ANd P. T. Tueller. 1977. Plant succession following changing of pinyonjuniper woodlands in eastern Nevada. Journal of Range Management 30:44-49.

Vasquez, E., R. Sheley, and T. Svejcar. 2008a. Creating invasion resistant soils via nitrogen management. Invasive Plant Science and Management 1:304-314.

Vasquez, E., R. Sheley, and T. Svejcar. 2008b. Nitrogen enhances the competitive ability of cheatgrass (Bromus tectorum) relative to native grasses. Invasive Plant Science and Management 1:287-295.

Young, J. A., And R. A. Evans. 1975. Germinability of seed reserves in a big sagebrush community. Weed Science 23:358-364.

Young, K. R. 2012. Plant establishment and soil microenvironments in Utah juniper masticated woodlands [thesis]. Provo, UT, USA: Brigham Young University. 103 p. 